\title{
SCIENTIFIC AND TECHNICAL COOPERATION BETWEEN UKRAINE AND CHINA IN THE CONTEXT OF GLOBALIZATION: SYNERGY OF INTELLECTUAL CAPITAL ${ }^{1}$
}

\section{НАУКОВО-ТЕХНІЧНЕ СПІВРОБІТНИЦТВО МІЖ УКРАЇНОЮ ТА КИТАЄМ В КОНТЕКСТІ ГЛОБАЛІЗАЦІї: СИНЕРГІЯ ІНТЕЛЕКТУАЛЬНОГО КАПІТАЛУ}

UDC 339.137.2:331.103

https://doi.org/10.32843/bses.59-6

\section{Shkola Viktoriia}

Candidate of Economic Sciences,

Associate Professor,

Senior Lecturer at Department

of International Economic Relations

Sumy State University

Omelyanenko Vitaliy

Candidate of Economic Sciences,

Associate Professor,

Senior Lecturer at Department

of Business Economics and Administration

Sumy State Pedagogical University

named after A.S. Makarenko

Petrenko Sofia

Student

Sumy State University

\begin{abstract}
The aim of the article is to study the main directions of scientific and technical cooperation between Ukraine and China in the context of ensuring the synergy of intellectual capital to achieve a stable level of their international competitiveness in the long run in the context of globalization. It is shown that international scientific and technical cooperation allows member countries to effectively integrate into the global innovation system on a competitive basis through the synergy of their intellectual capital. The role of intellectual capital in ensuring the international competitiveness of countries is explored. The growth of intellectual capital has been established to be ensured through development activities of its components (human capital, organizational capital, consumer capital and information capital), affecting each other, and the synergy of intellectual capital at global and national levels. A scientific and methodological approach to determine the synergetic effect of international scientific and technical cooperation achieved through the synergy of intellectual capital of the participating countries is proposed. Based on the analysis, the most promising areas of scientific and technical cooperation between Ukraine and China were identified.

Key words: intellectual capital, international scientific and technical cooperation, synergy, globalization.
\end{abstract}

Целью статьи является изучения основных направлений научно-технического comрудничества между Украиной и Китаем в контексте обеспечения синергии интел- лектуального капитала для достижения стабильного уровня их международной конкурентоспособности в долгосрочной перспективе в условиях глобализации. Показано, что международное научно-техническое сотрудничество позволяет странам-участницам эфрфективно интегрироваться в мировую инновационную систему на конкурсной основе за счет синергии интеллектуального капитала этих стран. Показана роль интеллектуального капитала в обеспечении международной конкурентоспособности стран. Исследование показало, что рост интеллектуального капитала достигается за счет применения мероприятий по развитию его составляющих (человеческого капиталу, организационного, потребительского и инсоормационного капиталу), которые взаимодействуют друг с другом, а также синергии интеллектуального капитала на различных уровнях (глобальном и национальном). Авторами предложен научно-методический подход к определению синергетического эфрфректа от международной научно-технической кооперации, достигаемого путем синергии интеллектуального капитала странучастниц. На основе проведенного анализа определены самые перспективные направления научно-технического сотрудничества между Украиной и Китаем.

Ключевые слова: интеллектуальный капитал, международное научно-техническое сотрудничество, синергия, глобализация.

В умовах посилення глобалізаційних процесів науково-технічне співробітництво створює передумови для економічного зростання країни, поліпшення добробуту та інтеграції у світовий економічний простір, що надзвичайно важливо для кожної країни світу, зокрема, України та Китаю. Метою статті є вивчення основних напрямків науково-технічного співробітництва між Україною та Китаєм в контексті забезпечення синергіі інтелектуального капіталу для досягнення стабільного рівня їх міжнародної конкурентоспроможності у довгостроковій перспективі в умовах глобалізації. Для ії досягнення визначеної мети передбачено вирішення таких завдань: дослідити сутність інтелектуального капіталу та визначити його роль у забезпеченні міжнародної конкурентоспроможності країни; дослідити науково-технічне співробітництво як важливу складову міжнародних економічних відносин в умовах глобалізації; проаналізувати конкурентні позиції України та Китаю в міжнародному науково-технічному середовищі; визначити особливості двостороннього науково-технічного співробітництва в епоху глобалізації; визначити результати та досягнення Китаю та України в розвитку авіаційної та ракетно-космічної техніки. Встановлено, що міжнародне науково-технічне співробітництво дозволяє країнам-учасницям есрективно інтегруватися у світову інноваційну систему на конкурентних засадах за рахунок синергії інтелектуального капіталу цих країн. Показано роль інтелектуального капіталу у забезпеченні міжнародної конкурентоспроможності країн. Встановлено, що зростання інтелектуального капіталу можливо забезпечити за рахунок активізації заходів з розвитку його складових (людського капіталу, організаційного, споживчого капіталу та інформаційного капіталу), які взаємодіють один з одним, а також синергії інтелектуального капіталу на різних рівнях (глобальному та національному). Запропоновано науково-методичний підхід до визначення синергетичний есректу від міжнародної науково-технічної кооперації, що гуртується на синергії інтелектуального капіталу країн-учасниць. На основі проведеного аналізу визначено найбільш перспективні напрямки науково-технічного співробітництва між Україною та Китаєм.

Ключові слова: інтелектуальний капітал, міжнародне науково-технічне співробітництво, синергія, глобалізація.

Statement of the problem. In the age of globalization, particular attention is being focused on one form of international economic relations - international scientific and technical cooperation. Science and technology create the preconditions for economic growth of the country, improvement of well-being and integration into the world economic space, which is extremely important for every country in the world, including Ukraine and China.

The relations between Ukraine and China are crucial in terms of geopolitical factor, which is manifested in the proximity of the positions of both

${ }^{1}$ The article is published within the Grant no. 0120 U102003 "Process of formation of the novel ecologically safe fertilizers with prolonged action based on the phosphorite deposits raw material" financed by Ministry of Science and Education of Ukraine 
countries on the key problems of modern political development, the absence of acute problems in bilateral relations. Countries are gradually taking joint steps towards mutually beneficial cooperation, since they both have a common goal - integration into the global economic community through the development of an innovative economy. This orientation can turn these countries into strategic partners, especially in the field of scientific and technical cooperation, which will ensure their international competitiveness through the synergy of intellectual capital of both countries. Therefore, it is relevant to consider ways of productive development of the international scientific and technical cooperation between these countries.

Analysis of the recent research and publications. The issue of the impact of globalization on the development of economic systems has been studied by domestic and foreign scholars, in particular [1-4]. The works [5-9] are devoted to the study of the role of intellectual capital in the formation of sustainable competitive advantages and competitiveness of enterprises and countries. However, despite thorough scientific research, the problem of scientific substantiation of the intellectual capital synergy ensuring the long-term competitiveness of member countries of international scientific and technical cooperation remains unresolved.

Formulation of the goals of the article (task statement). The objective of the article is to examine main directions of scientific and technical cooperation between Ukraine and China, ensuring synergy of intellectual capital to achieve their stable international competitiveness for long term in the context of globalization. To achieve the goal, the following tasks are supposed to be solved, namely: to study the essence of intellectual capital and it role in ensuring international competitiveness of country; to characterize scientific and technical cooperation as an important component of international economic relations in the context of globalization; to analyze the competitive position of Ukraine and China in international scientific and technical environment; to identify the features of bilateral scientific and technical cooperation in the era of globalization; to determine the results and achievements of China and Ukraine in the field of rocket and aircraft.

The main body. Globalization processes of today consist of the large-scale processes of economic and political, and socio-cultural integration (related to rapprochement, ordering of relations in spatial aspect) and unification (reduction to a single basis, standardization). The consequences of globalization are informatization of society together with the spread of information and communication technologies (computers, software, storage and audiovisual systems, telephone lines and wireless connections, etc.), the Internet; the exchange of results of production underpinning the international division of labor has become more productive, because over the years economically profitable specialization and exchange between regions and countries has become evident; economic tasks are increasingly being solved on a joint basis - through partnership efforts, which is an international production cooperation; the result of globalization is overflow, movement of resources (natural, material, financial, labor); the interconnection and adaptation of national economies, namely international economic integration and the creation of a single global market.

Globalization serves as the basis for the transformation of international economic relations, which is a system of relations between entities from different countries regarding the production, distribution, exchange and consumption of goods, services, capital, ideas in the context of resource constraints and international division of labor within the World Economy. One of the main forms of the international economic relations is international scientific and technical cooperation, covering trade in licenses, joint scientific development, implementation of major technical projects, construction of enterprises and other objects, exploration, training of national personnel, exchange of general scientific and technical information [10]. International scientific and technical cooperation allows member countries to effectively integrate into the global innovation system on a competitive basis through the synergy of these countries' intellectual capital of (Figure 1).

Studying relationship between intellectual capital and operational excellence, Dhamija P. [7] has regarded intellectual capital as the crucial wealth of every company and the root of its successful operational management.

Broadly, llyashenko S. [8] has understood intellectual capital as a set of tangible and intangible intellectual resources and the ability to implement them, which determine the ability of the enterprise to develop on the basis of information and knowledge. Melnik L. [9] has considered this definition as the intellectual abilities of people, as well as the tangible and intangible means created by them and utilized for intellectual work.

The growth of intellectual capital is ensured through both development of its components (human capital, organizational capital, consumer capital and information capital), affecting each other, and the synergy of intellectual capital at global and national levels. In general, the synergistic effect (Es) is proposed to be culculated by the formula

$$
E_{s}=\sum_{i=1}^{n} \sum_{j=1}^{k} I C_{i} \cdot E_{j} \cdot S_{j}^{m},
$$

where $n$ is the total number of economic systems interacting with each other; $i$ is ordinal number of the economic system, $i \in[1 ; n] ; j$ is the ordinal number of directions of economic systems cooperation, $\mathrm{j} \epsilon[1 ; \mathrm{k}]$; $k$ is the total number of directions of economic systems cooperation, affecting intellectual capital level; 


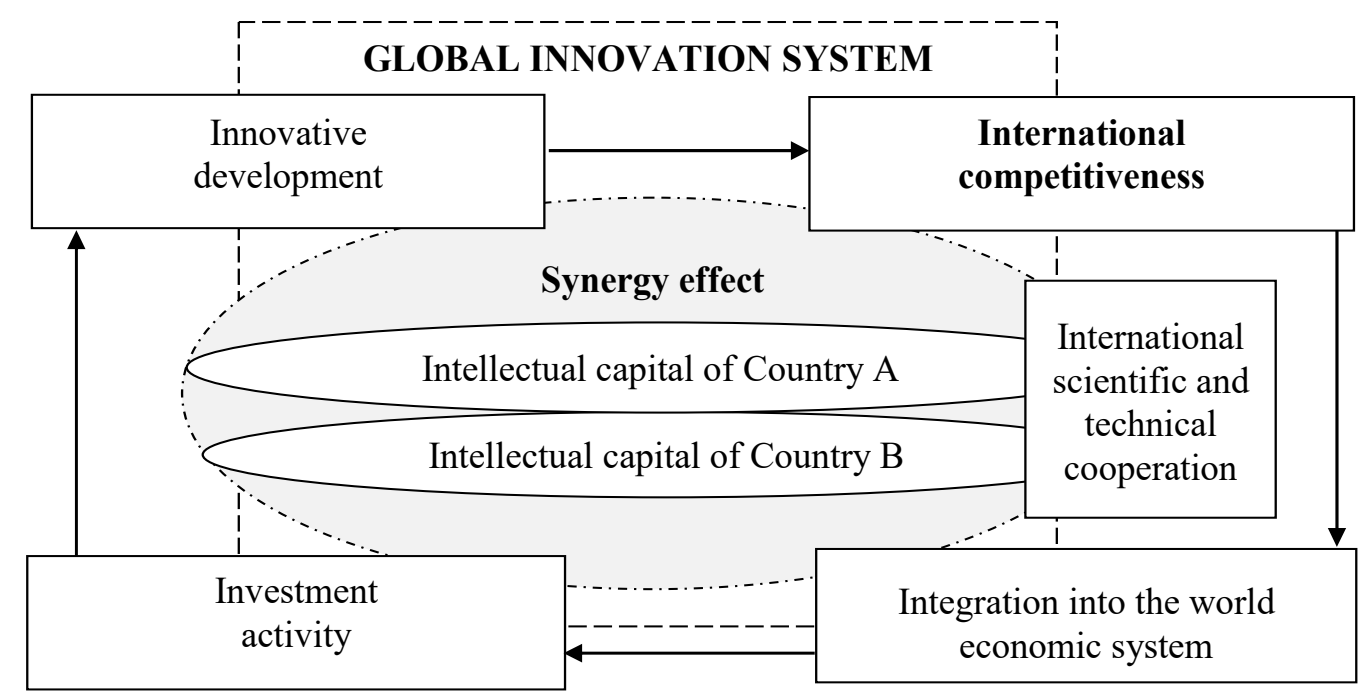

Figure 1. The role of intellectual capital in ensuring international competitiveness of countries (own elaboration based on [4])

IC means measures of the i country's intellect capital; $E$ is the expected effect of the $j$ direction impacting; $\mathrm{Sj}$ is the synergy coefficient, characterizing the additional influence of the $\mathrm{j}$ direction; $m$ is an exponent that ranges from +1 to -1 depending on the influence of the j direction (increasing or decreasing, respectively).

The Ukrainian-Chinese cooperation is characterized by high level of trust and understanding, lack of fundamental differences in foreign policy positions, approximation of approaches to solving important international problems. Regular high-level visits are a testament to the high level of development of bilateral relations. China is one of the first countries to support Ukraine's independence, proclaimed in 1991 , and since January 4, 1992, diplomatic relations have been established between the states [11].

Main documents providing basis for long-term scientific and technical cooperation between Ukraine and China are the Agreement on Scientific Cooperation between the National Academy of Sciences of Ukraine and Chinese Academy of Social Sciences (03.05.1999), the Protocol on the Establishment of the Joint UkrainianChinese Commission on Scientific and Technical Cooperation (05.1997), the Declaration on Further Strengthening of Trade, Economic, Scientific and Technical Cooperation, Protocol of the Second meeting of the Subcommittee on Scientific and Technical Cooperation of the Commission for Cooperation between the Government of Ukraine and the Government of China (2016), Protocol between the Government of Ukraine and the Government of the People's Republic of China on amendments and supplements to the Agreement between the Government of Ukraine and the Government of the People's Republic of China on military and technical cooperation (18.04.2001) [11].

According to the Agreement between the Government of Ukraine and the Government of the People's Republic of China on Scientific and
Technological Cooperation (27.04.1992) regulating bilateral relations in this area, the following main forms of cooperation are envisaged: 1) joint research and development, as well as sharing the results of research and development of mutual interest; 2) exchange of scientific and technical information and documentation, samples of products and materials, as well as exchange of know-how and licenses on a compensatory basis; 3)organization of scientific and technical seminars, symposia and scientific conferences; 4) exchange of scientific and technical delegations, individual scientists and specialists, training and internship of scientific personnel; 5) other mutually agreed forms of scientific and technical cooperation [12].

The main mechanism for implementing the NTS between Ukraine and China as a priority area of bilateral relations is the Cooperation Commission between the Government of Ukraine and the Government of the People's Republic of China (established in 2011), as well as a number of specialized Sub-Commissions dealing with scientific and technical cooperation, cooperation in space and medicine [13].

China supports and funds the creation of technoparks by specific types of research activities by the Ukrainian research institutes on its territory. For example, it is the Ukrainian-Chinese Center for Welding and Related Technologies in Harbin, an agreement on the creation of which was signed between

E.O. Paton Electric Welding Institute of NAS of Ukraine and Harbin Welding Institute. Since its inception, the institute has focused on creating innovation across multiple industries. These are technologies and equipment for contact welding of pipelines and fittings that open up new opportunities in the construction of reinforced concrete bridges, overpasses and highways. In addition, these are aluminum alloy joints used in shipbuilding. Also these are technologies of restoration of details by high- 
speed plasma spraying, which will find application in the textile industry, printing [14].

An important promising aspect of the expansion of the Ukrainian-Chinese cooperation in science, technology and innovation is the creation of joint research laboratories, centers, research, educational and scientific production integrated structures (while this form of cooperation is being discussed between the NAS of Ukraine and the Harbin Institute of Technology, one of the leading educational and scientific institutions of China) [14].

The main directions of scientific and technical cooperation between China and Ukraine are those intending to:

1) develop mutually beneficial relations in the implementation of joint projects aimed at the development of nuclear energy and the nuclearindustrial complex by: developing scientific and technical cooperation on the issues related to the peaceful use of nuclear energy;

2) establish industrial parks in Ukraine with the participation of Chinese investors and funds;

3) develop cooperation in the field of space exploration and utilization, in particular the implementation and periodic updating of the Program of the Ukrainian-Chinese Space Cooperation [15].

It should be noted that by 2035 China intends to launch some launch vehicles designed by its own, by 2020-2022 - a manned space station, by 2050 a solar power plant. China means to make a major breakthrough in the creation of "nuclear-powered space shuttles" by 2040 [16].

Ukraine participates in many international projects in the space industry, cooperates extensively with foreign partners, including China. Thus, in 1995, the Ukrainian-Chinese Subcommittee on Co-operation in the Field of Outer Space Development for Peaceful Purposes was established. Ukraine's position in space is the strongest in the launch services market. China is interested in developing its own satellite navigation system, while Ukraine is interested in receiving microelectronics and investment technologies. Therefore, stable and promising cooperation between the PRC and Ukraine can be established and stabilized in these areas.

In addition, several agreements on the modernization and maintenance of Chinese aviation equipment were signed at the aerospace exhibition in the Chinese city of Zhuhai, including the modernization of the Chinese U-8 aircraft, which is a copy of the Ukrainian AN-12 aircraft.

Currently, Ukraine is involved in the implementation of Chinese AVIC I and AVIC II projects to create a new regional ARJ-21 and a new transport Y8F600. The ARJ-21 is a 60-90 seat jet that is expected to be the mainstay of regional airlines in the 21st century. The prototype for it could be the AN-74, in which, however, the Chinese are asked to make a number of structural improvements [17]. According to expert estimates, the potential volume of military-technical cooperation between countries is estimated at least hundreds of millions of dollars annually [18].

Conclusion. Scientific and technical cooperation plays a major role in raising science and technology to a new level, as well as in developing the economies of the participating countries. Not even the most economically advanced country in the world can fully carry out research in all areas of scientific knowledge at the same time. Therefore, along with the country's participation in the bidding in the world technology market, the international scientific and technical cooperation is a significant auxiliary force for ensuring compliance with the national level of scientific and technological development.

Using the experience and financial resources of China, Ukraine needs to increase the scientific and technical level by introducing the latest technologies in cooperation with multinational corporations and other technology owners, creating domestic technology parks and export enterprises. Promising directions towards bilateral scientific and technical cooperation are the shipbuilding and aerospace industries, the agro-industrial sector, as well as joint research in the field of materials science, solid-state physics, radio electronics, low temperatures, and magnetism.

\section{REFERENCES:}

1. Matveev Yu. V. (2010) Peculiarities of interaction of globalization and competitiveness of economy. Economic Sciences, no. 7 (68), pp. 9-17.

2. Scott D. Johnson, Elizabeth Faye Gatz, Don Hicks (1997) Expanding the Content Base of Technology Education: Technology Transfer as a Topic of Study. Journal of technology education, vol. 8, no. 2.

3. Nartova I.V., Kolomiiets Ye.O. (2011) Hlobalizatsiia ta ii vplyv na rozvytok svitovoho hospodarstva [Globalization and its impact on the development of the world economy]. Scientific Bulletin of Poltava University of Economics and Trade, no. 3 (48), pp. 20-24.

4. Shkola V.Yu., Omelyanenko V.A., Kasianenko T.V. (2019) Stratehichnyi vymir vplyvu hlobalizatsii na rozvytok natsionalnoi innovatsiinoi systemy [Strategic dimension of the impact of globalization on the development of the national innovation system]. Black Sea Economic Studies, no. 45, pp. 12-15. Available at: http://bses.in.ua/journals/2019/45_2019/4.pdf.

5. De Courcy, J. Research (2007) Joint Ventures and International Competitiveness: Evidence from the National Cooperative Research Act. Economics of Innovation and New Technology, vol. 16, no. 1, pp. 51-65(15).

6. Utkina Yu.M. (2016) Intelektualnyi kapital yak faktor zabezpechennia konkurentostiikosti pidpryiemstv $v$ hlobalnii ekonomitsi [Intellectual capital as a factor of ensuring competitive stability of the enterprise in the global economy. Bulletin of Transport Economics and Industry, no. 56, pp. 58-67. Available at: http://lib.kart.edu.ua/ bitstream/123456789/793/1/NETP_2016_56_58_63.pdf. 
7. Dhamija P. (2020) Intellectual Capital and Operational Excellence: An Influential Assessment. International Journal of Mathematical, Engineering and Management Sciences, vol. 5, no. 6, pp. 1062-1076. Available at: https://doi.org/10.33889/IJMEMS.2020.5.6.081.

8. Illyashenko S.M. (2008) Sutnist, struktura I metodychni osnovy otsinky intelektualnoho kapitalu pidpryiemstva [The essence, structure and metho-dological basis for assessing the intellectual capital of the enterprise]. Ukraine economy, no. 11, pp. 16-26.

9. Melnik L.G. (2005) Ekonomika i informatsiya: ekonomika informatsii i informatsiya $v$ ekonomike entsiklopedicheskiy slovar' [Economics and information: economics of information and information in economics: an encyclopedic dictionary]. Sumy: PTH "University Book"

10. Bazylevych V.D. (2007) Politekonomiia: pidruchnyk [Political Economy: a textbook]. Kyiv: Knowledge-Press, 2007.

11. Legal Basis of Ukraine and China. Embassy of Ukraine to the People's Republic of China. Available at: https://china.mfa.gov.ua/en/partnership/184-dogovirnopravova-baza-mizh-ukrajinoju-ta-kitajem.

12. Agreement between the Government of Ukraine and the Government of the People's Republic of China on scientific and technological cooperation (27.04.1992). Available at: http://uainfo.biz/legal/basegi/ua-rmpwwe.htm.

13. Embassy of Ukraine to the People's Republic of China (2020) Naukovo-tekhnichne spivrobitnytstvo mizh Ukrainoiu ta Kytaiem [Scientific and technical cooperation between Ukraine and China]. Available at: https://china.mfa.gov.ua/spivrobitnictvo/-kitajem.

14. Kiktenko V.O. (2007) Doslidzhennia Kytaiu v nezalezhnii Ukraini [Research of China in independent Ukraine]. Ukraine - China. Special issue, no. 1 (7), pp. 108-117.

15. Ministry of Economic Development and Trade of Ukraine (2017) Plan dii Ukraina - Kytaiska Narodna Respublika z realizatsii initsiatyvy spilnoho budivnytstva "Ekonomichnoho poiasu shovkovoho shliakhu" $i$ "Morskoho shovkovoho shliakhu XXI stolittia [Ukraine-China People's Republic Action Plan for the Joint Construction of the Silk Road Economic Belt and the 21st Century Maritime Silk Road]. Available at: http://www.me.gov.ua/ DocumentsZKitaiskoiuNarodnoiuRespublikoi.

16. Kiktenko V.O. (2018) Kosmichni obrii socialnoekonomichnoho pidomu Kytaiu [Space horizons of China's socio-economic rise]. Ukraine - China, no. 12 , pp. 44-47. Available at: http://sinologist.com.ua/wp-content/uploads/2018/07/ukraine-chine-n12 6.pdf.

17. Badrak V., Zhurets S., Bohdanov D., Kopchak V., Nabochenko O., Yarovyi A. (2017) Ukraina - Kytai: vid proektiv do stratehichnoho partnerstva [Ukraine - China: from projects to strategic partnership]. Kyiv: Center for Research, Army, Conversion and Disarmament.

18. State Space Agency of Ukraine. Available at: http://www.nkau.gov.ua/gateway/news.nsf/NewsALLR/2 AFFB332D2D74531C22570840024BB1F!open.

\section{БІБЛІОГРАФІЧНИЙ СПИСОК:}

1. 1. Matveev Yu. V. Peculiarities of interaction of globalization and competitiveness of economy. Economic Sciences. 2010. № 7 (68), pp. 9-17.

2. 2. Scott D. Johnson, Elizabeth Faye Gatz and Don Hicks. Expanding the Content Base of Technology Education: Technology Transfer as a Topic of Study. Journal of technology education. 1997. Vol. 8. № 2.
3. Нартова І.В., Коломієць Є.О. Глобалізація та її вплив на розвиток світового господарства. Науковий вісник Полтавського університету економіки і торгівлі. 2011. № 3 (48). С. 20-24.

4. Школа В.Ю., Омельяненко В.А., Касьяненко Т.В. Стратегічний вимір вливу глобалізації на розвиток національної інноваційної системи. Причорноморські економічні студії. 2019. Вип. 45. С. 12-15. URL: http://bses.in.ua/journals/2019/45_2019/4.pdf

5. De Courcy, J. Research. Joint Ventures and International Competitiveness: Evidence from the National Cooperative Research Act. Economics of Innovation and New Technology. 2007. Vol. 16. № 1. pp. 51-65(15).

6. Уткіна Ю.М. Інтелектуальний капітал як фрактор забезпечення конкурентостікості підприємств в глобальній економіці. Вісник економіки транспорту і промисловості. 2016. № 56. С. 58-67. URL: http://lib.kart.edu.ua/bitstream/123456789/793/1/ VETP 20165658 63.pdf.

7. Dhamija P. Intellectual Capital and Operational Excellence: An Influential Assessment. International Journal of Mathematical, Engineering and Management Sciences. 2020. Vol. 5. No. 6. 1062-1076. https://doi.org/ 10.33889/IJMEMS.2020.5.6.081.

8. Ілляшенко С.М. Сутність, структура і мето-дичні основи оцінки інтелектуального капіталу підприємства. Економіка України. 2008. № 11. С. 16-26.

9. Мельник Л.Г. Экономика и информация: экономика информации и инфрормация В экономике : энциклопедический словарь. Суми : ИТД «Университетская книга», 2005. 384 с.

10. Базилевич В.Д. Політекономія: підручник; 6-е вид., перероб. і доп. Київ : Знання-Прес, 2007. 719 с.

11. Embassy of Ukraine to the People's Republic of China (2020) Legal Basis of Ukraine and China. URL: https://china.mfa.gov.ua/en/partnership/184-dogovirno-pravova-baza-mizh-ukrajinoju-ta-kitajem.

12. Agreement between the Government of Ukraine and the Government of the P.R. China on scientific and technological cooperation (27.04.1992). URL: http://uainfo.biz/legal/basegi/ua-rmpwwe.htm.

13. Посольство України в Китайській Народній Республіці та в Монголії (за сумісництвом): «Науковотехнічне співробітництво між Україною та Китаєм». URL: http://china.mfa.gov.ua/ua/ukrainecn/science.

14. Кіктенко В.О. Дослідження Китаю в незалежній Україні. Україна - Китай. Спеціальний випуск. 2017. № 1 (7). С. 108-117

15. Офріційний сайт: Міністерство економічного розвитку і торгівлі України. URL: http://www.me.gov.ua/ Documents/Detail?lang=uk-UA\&id=53b0b352-76b54a218511748df9c6765f\&title=SpivrobitnitstvoZKitaiskoiuNarodnoiuRespublikoiu.

16. Кіктенко В.О. Космічні обрії соціальноекономічного підйому Китаю. Україна - Китай. 2018. № 12. C. 44-47. URL: http://sinologist.com.ua/wp-content/uploads/2018/07/ukraine-chine-n12_6.pdf.

17. Бадрак В., Згурець С., Богданов Д., Копчак В., Набоченко О., Яровий А. Україна - Китай: від проектів до стратегічного партнерства. Київ : Центр досліджень, армії, конверсії і роззброєння, 2017. 94 с.

18. State Space Agency of Ukraine. URL: http://www.nkau.gov.ua/gateway/news.nsf/NewsALLR/2AFFB332D2D74531C22570840024BB1F!open. 